\title{
BOEKENSIGNALEMENT
}

\section{Inleiding bij de dubbelrecensie Wij zijn ons en Veerkrachtig bestuur}

\author{
Duco Bannink*
}

De titel van ons tijdschrift, Beleid en Maatschappij, laat het al zien: wij zijn geïnteresseerd in de relatie tussen beleid en maatschappij. Het is daarom dat we erg blij zijn met de dubbelrecensie van Wij zijn ons en Veerkrachtig bestuur. Wij zijn ons van Mark van Ostaijen wordt gerecenseerd door Willem Trommel en Veerkrachtig bestuur van Willem Trommel wordt gerecenseerd door Mark van Ostaijen, Beiden zijn geïnteresseerd in het verband tussen bestuur en samenleving en beiden zijn socioloog, maar terwijl Trommel (werkend in een afdeling Bestuurskunde) werkt vanuit de vraag naar de aard van het bestuur in een samenleving onder druk, werkt Van Ostaijen vanuit de vraag naar de aard van de samenleving, mede onder druk van veranderend bestuur. Ze zijn het eens over één centraal punt en dat is het belang van de sociologie. Uit Trommel volgt: als we nadenken over hoe bestuur eruitziet of er uit zou moeten zien, kunnen we niet om de vraag heen waarin dat bestuur eigenlijk plaatsvindt - in een samenleving. Uit Van Ostaijen volgt: als we actuele maatschappelijke kwesties niet meer sociologisch beschouwen, missen we belangrijke aspecten - wij zijn niet 'ons brein', en dus individuen met onze individuele breinen, wij zijn 'ons'.

Ze zijn het niet helemaal eens, natuurlijk. Als je het heel grof beschouwt, zegt Trommel over Van Ostaijen dat hij te weinig politiek is (bevrijd de sociologie van de narrenstatus!), en zegt Van Ostaijen over Trommel dat hij te veel politiek is (wat is eigenlijk die crafting community waar je het over hebt?).

Wij zijn erg blij met de dubbelrecensie, omdat die hoe dan ook op de kaart zet dat bestuurskunde een sociale wetenschap is en dat het begrijpen van het functioneren van een samenleving een sociaalwetenschappelijke benadering behoeft.

* Dr. Duco Bannink is lid van de redactie van Beleid en Maatschappij. 